\title{
Funkcjonowanie francuskiego modelu rejestracji stanu cywilnego w Polsce
}

I. Pośród licznych zmian, które przyniosła Wielka Rewolucja Francuska, pamiętać należy również o reformie systemu rejestracji stanu cywilnego, choć wydawać się ona może mniej spektakularna od innych. Nowy model rejestracji zasługuje jednak na szczególną uwagę, ponieważ jego wprowadzenie oznaczało zeświecczenie sfery, która wydawała się trwale podporządkowana związkom wyznaniowym. Już konstytucja z 3 września 1791 r. stanowiła, że: „Władza ustawodawcza ustali dla wszystkich bez różnicy mieszkańców sposób, w jaki będzie się stwierdzać narodziny, zawarcie małżeństwa, zgony, i wyznaczy urzędników publicznych, którzy obejmą i będą przechowywali dokumentację" (tytuł II, art. 7) ${ }^{1}$. Dyrektywę tę zrealizował dekret o aktach stanu cywilnego, małżeństwie i rozwodzie z 20 września 1792 r., który stanowił: „Akty stwierdzające urodziny, zawarcie małżeństwa i zgony będą w posiadaniu i pod pieczą na przyszłość zarządów gminnych"”2. Funkcję urzędników stanu cywilnego powierzono merom, nad którymi - w tym zakresie - nadzór sprawowali początkowo prefekci, a następnie trybunały pierwszej instancji ${ }^{3}$. W ówczesnej Europie było to rozwiązanie nietypowe,

1 „Le Pouvoir législatif établira pour tous les habitants, sans distinction, le mode par lequel les naissances, mariages et décès seront constatés; et il désignera les officiers publics qui en recevront et conserveront les actes". L. Duguit, H. Monnier (wyd.), Les constitutions et les principales lois politiques de la France depuis 1789, Paris 1898, s. 6.

2 „Les municipalités recevront et conserveront à l'avenir les actes destinés à constater les naissances, mariages et décès”. J.B. Duvergier (wyd.), „Pasinomie, ou Collection complète des lois, décrets, arrêtéset règlements généraux qui peuvent être invoqués en Belgique", t. IV, Bruxelles, 1834, s. 442. Tłum.: Powszechna historia państwa i prawa. Wybór tekstów źródłowych, oprac. B. Lesiński, J. Walachowicz, Poznań 1975, s. 165.

${ }^{3}$ G. Noiriel, L'identification des citoyens. Naissance de l'état civil républicain, „Genèses. Sciences sociales et histoire" 1993, nr 13, s. 21; D. Dzierożyński, Instrukcja dokładna o urzędnikach i aktach stanu cywilnego, Warszawa 1813, s. 3. 
gdyż w tych państwach, które przejęły od instytucji wyznaniowych jurysdykcję w sprawach małżeńskich (takich jak Prusy czy Monarchia Habsburgów), prowadzenie rejestrów narodzin (chrztów), małżeństw i zgonów pozostawało zasadniczo w gestii przełożonych poszczególnych parafii.

Wprowadzenie tak poważnej reformy we Francji nie odbyło się rzecz jasna bezproblemowo ${ }^{4}$. Funkcje merów (i ich zastępców, którym nieraz powierzano spisywanie aktów) sprawowały często osoby słabo wykształcone i nie zawsze dobrze rozumiejące ideę służby publicznej. Problemy wynikały też z tego, że wielu merów słabo znało francuski, gdyż na co dzień posługiwali się jego dialektami lub też językiem włoskim czy niemieckim. Księgi bywały spisywane nieczytelnie i z błędami ortograficznymi. Często brakowało podpisów stron pod aktami. Zdarzało się też ich antydatowanie. Ponadto niejednokrotnie spóźniano się z przekazywaniem ksiąg do archiwizacji. Bywali nawet urzędnicy, którzy sporządzali akty dotyczące ich własnych małżeństw ${ }^{5}$.

Wobec tych problemów nie może dziwić, że w Kodeksie Napoleona znalazły się szczegółowe unormowania dotyczące prowadzenia akt stanu cywilnego (tytuł II księgi pierwszej). Wraz z całym kodeksem 1 maja $1808 \mathrm{r}$. stały się one na obszarze Księstwa Warszawskiego obowiązującym prawem. Wprowadzenie ich w życie na podległych Napoleonowi ziemiach polskich było jednak jeszcze trudniejsze niż we Francji, zwłaszcza że recepcja napoleońskiego modelu administracyjnego okazała się możliwa jedynie częściowo. Na wzór francuski zorganizowano w Księstwie tylko departamenty i odpowiadające okręgom powiaty. Nie udało się natomiast urządzić w terenie administracji gminnej, wpisującej się w model francuski - scentralizowany i sprofesjonalizowany. O ile w miastach francuskim merom odpowiadali do pewnego stopnia burmistrzowie i prezydenci, o tyle na wsi profesjonalnego aparatu biurokratycznego w ogóle nie powołano. Pewne funkcje merów (i ich aparatu) spełniali wójtowie (którymi często zostawali miejscowi ziemianie lub osoby przez nich wskazane), a także proboszczowie i inne osoby, którym powierzono funkcje urzędników stanu cywilnego.

Zasady nominacji urzędników stanu cywilnego uregulowało urządzenie ułożone na sesji Rady Ministrów 21 kwietnia 1808 r. ${ }^{6}$ Zgodnie z nim wyspe-

${ }^{4}$ Pomimo że początków reformy można się doszukiwać za ancien régime'u. I. Malinowska-Kwiatkowska, Matżeństwo przed urzędnikiem świeckim w przedrewolucyjnej Francji, Acta Universitatis Nicolai Copernici, Nauki Humanistyczno-Społeczne. Prawo, t. XXX, 2, 218, s. 181 i n.

${ }^{5}$ G. Noiriel, L'identification..., s. 8-25; Jeszcze trudniejsze niż we Francji właściwej okazało się zaprowadzenie akt stanu cywilnego nowego typu w Prowincjach Iliryjskich, gdzie przeważnie prowadzenie ksiąg pozostało w gestii proboszczów - M. Senkowska-Gluck, Rządy francuskie w Ilirii. Przyklad nieudanej recepcji obcych instytucji, CPH, t. XXVII (1975), z. 2 , s. 246.

${ }^{6}$ AGAD, Rada Stanu i Rada Ministrów Księstwa Warszawskiego, seria 2, t. 76, s. 1-2; Archiwum Diecezjalne w Łomży, Akta Urzędników Stanu Cywilnego, sygn. 448, k. 11v-12. Ewa Ziółek podaje błędną datę powstania omawianego aktu (21 maja 1808 r.); eadem: Między tronem i oltarzem. Kościót i państwo w Księstwie Warszawskim, Lublin 2012, s. 115. Za nią datę tę powta- 
cjalizowani urzędnicy stanu cywilnego - nie łączący prowadzenia rejestrów stanu cywilnego z inną funkcją publiczną - mieli zostać powołani jedynie w Warszawie (pkt 6). W pozostałych zaś miastach rejestry powierzono prezydentom i burmistrzom (pkt 1), a ,we wsiach, w których są parafie, a nie ma znacznej ilości Żydów”, księżom proboszczom (pkt 2). We wsiach zamieszkałych przez licznych różnowierców należało wyznaczyć kogoś innego niż proboszcza - np. organistę (pkt 3). Tym niemniej z protokołu Rady Stanu z 15 marca 1808 r. wynika, że minister sprawiedliwości już wówczas rozsyłał do proboszczów „formularze, podług których mają być zapisywane” akta stanu cywilnego ${ }^{7}$.

Stan normatywny uległ istotnej zmianie wraz z wejściem w życie dekretu z 13 lutego 1809 r. Taxa optat dla Urzędników Stanu Cywilnego tak świeckich, jako i duchownych w Księstwie Warszawskim ${ }^{8}$. Artykuł 1 tegoż dekretu powierzał prowadzenie akt stanu cywilnego duchownym pełniącym obowiązki parafialne (tak katolickim, jak i należącym do innych wyznań chrześcijańskich - o czym niżej). Dekret przewidywał możliwość sprawowania obowiązków urzędników stanu cywilnego przez osoby świeckie tylko w odniesieniu do aktów niezgodnych z prawem kanonicznym (rozwody, śluby wyłącznie cywilne i ich zapowiedzi). Funkcje te mieli pełnić burmistrzowie i prezydenci miast (art. 4). Milczeniem pominięto natomiast działalność świeckich urzędników stanu cywilnego w Warszawie i innych miejscowościach. Literalna wykładnia dekretu sugerowałaby zatem, że zostali oni zniesieni ${ }^{9}$. Z zachowanych dokumentów praktyki wiadomo jednak, że świeccy urzędnicy stanu cywilnego pracowali aż do roku $1825^{10}$.

W literaturze dominuje pogląd, że poza Warszawą (i ewentualnie niektórymi miejscowościami, gdzie ludność była wyznaniowo niejednolita) akta stanu

rza Marzena Dyjakowska, eadem, Rejestracja stanu cywilnego w Księstwie Warszawskim i w Królestwie Polskim, „Metryka” 2013, nr 1, s. 19. Pełna treść urządzenia w aneksie do niniejszego artykułu.

7 Protokoły Rady Stanu Księstwa Warszawskiego 1807-1813, wyd. B. Pawłowski, T. Mencel, M. Kallas, t. I, cz. 1, Torun 1964, s. 199. Brzmienie jednej z towarzyszących im nominacji przedstawia ks. Witold Jemielity w: Akta stanu cywilnego w Księstwie Warszawskim i Królestwie Polskim, „Prawo Kanoniczne” 1995, nr 1-2 (38), s. 165-166.

${ }^{8}$ Dziennik Praw, t. I, s. 195 i n. Dodajmy, że ustawa z 18 marca 1809 r. przeniosła obowiązki związane $\mathrm{z}$ nadzorem nad aktami stanu cywilnego z trybunałów cywilnych na sądy pokoju. Dziennik Praw, t. I, s. 231 i n.

9 Stąd - być może - wzięły się poglądy literatury, iż proboszczowie nie od razu zajęli się aktami: A.J. Nowowiejski, Pasterologia, Płock 1930, s. 107; A. Molisiak, Akta stanu cywilnego, [w:] Nauka pasterzowania, pod red. Z. Pilcha, Kielce 1939, t. I, s. 154; W. Jemielity, Akta stanu cywilnego..., s. 164.

$10 \mathrm{~Np}$. Archiwum Miasta Stołecznego Warszawy, Akta stanu cywilnego gminy warszawskiej I cyrkułu (72/183); Archiwum Państwowe w Płocku, Akta stanu cywilnego gminy Płock 1808-1825 (50/357), t. 83; Archiwum Państwowe w Lublinie, Akta stanu cywilnego Parafii Rzymskokatolickiej w Zamościu (35/1954), t. 40: Księga ogłoszenia rozwodów i dawania ślubów cywilnych. 
cywilnego prowadzili wyłącznie proboszczowie parafii rzymskokatolickich ${ }^{11}$. Tymczasem badania archiwalne wskazują, że choć istotnie wśród urzędników stanu cywilnego na prowincji przeważali proboszczowie, nierzadko obowiązki te pełniły osoby spoza ich grona. Można przy tym wyróżnić cztery zasadnicze kategorie urzędników stanu cywilnego: 1) proboszczowie parafii rzymskokatolickich; 2) przełożeni parafii innych związków wyznaniowych; 3) osoby świeckie prowadzące kompleksowo akta stanu cywilnego; 4) osoby świeckie prowadzące specjalne księgi akt stanu cywilnego, równoległe do tych sporządzanych przez miejscowego proboszcza, służące do odnotowywania wydarzeń niezgodnych z prawem kanonicznym (rozwody, śluby wyłącznie cywilne $\mathrm{i}$ ich zapowiedzi) ${ }^{12}$.

II. Działalność proboszczów w roli urzędników stanu cywilnego jest stosunkowo dobrze znana, stąd też wystarczy przypomnieć, że sprawowali oni swoje funkcje również w stosunku do ludności niekatolickiej - zwłaszcza Żydów ${ }^{13}$. Zdarzało się nawet, że zakładali dla nich osobne księgi ${ }^{14}$. Zresztą, jak podaje Włodzimierz Dworzaczek, także przed rozbiorami innowiercy (w szczególności protestanci) korzystali nieraz z katolickich ksiąg metrykalnych ${ }^{15}$. W badanym okresie $\mathrm{z}$ takimi praktykami spotkać się możemy w spo-

11 W. Dworzaczek, Genealogia, Warszawa 1959, s. 60; I. Dybus-Grosicka, Poczatki i rozwój rejestracji stanu cywilnego na ziemiach polskich, [w:] „Prawo - Administracja - Kościół” 2006, nr 3(27), s. 76; M. Dyjakowska, Rejestracja..., s. 19; W. Jemielity, Akta stanu cywilnego..., s. 164; A. Molisiak, Akta Stanu ..., s. 154; A.J. Nowowiejski, Pasterologia ..., s. 107; W. Sobociński, Historia ustroju i prawa Księstwa Warszawskiego, Torun 1964, s. 181, K. Sójka-Zielińska, Prawo cywilne, [w:] Historia państwa i prawa Polski, pod red. J. Bardacha, Warszawa 1981, t. III, s. 138; T. Walachowicz, Kodeks Napoleona a kościelna dyscyplina matżeńska w dobie Księstwa Warszawskiego, „Roczniki Teologiczno-Kanoniczne” 1977, t. XXIV, z. 5, s. 142; E. Ziółek, Między tronem..., s. 114.

12 Archiwum Państwowe w Lublinie, Akta stanu cywilnego Parafii Rzymskokatolickiej w Zamościu (35/1954), t. 40: Księga ogłoszenia rozwodów i dawania ślubów cywilnych; Archiwum Państwowe w Kielcach, Akta Urzędnika Stanu Cywilnego powiatu kieleckiego (21/1143), t. 1-6.

13 P. Sygowski, Żydzi Janowca w latach 1811-1864 w świetle Ksiag Urzędu Stanu Cywilnego $z$ Archiwum Państwowego w Lublinie i Dokumentów Centralnych Władz Wyznaniowych z Archiwum Glównego Akt Dawnych w Warszawie, [w:] Historia i kultura Żydów Janowca nad Wista, Kazimierza Dolnego i Puław. Fenomen kulturowy miasteczka - sztetl. Materiały z sesji naukowej „,V Janowieckie Spotkania Historyczne”. Janowiec nad Wisła 28 czerwca 2003 r., Janowiec 2003, s. 51; Archiwum Państwowe w Białymstoku, Oddział w Łomży, Akta stanu cywilnego Parafii Rzymskokatolickiej w Łomży, t. 60, akt nr 20 i 31; Archiwum Państwowe w Suwałkach, Akta stanu cywilnego Parafii Rzymskokatolickiej w Augustowie (63/148), t. 1, akt nr 1.

${ }^{14} \mathrm{~Np}$. Archiwum Państwowe w Piotrkowie Trybunalskim, Akta stanu cywilnego gminy Brzeziny (49/443), t. 2: Akta cywilne urodzenia żydowskiego gminy parafii brzezińskiej powiatu brzezińskiego w departamencie warszawskim; P. Sygowski, Żydzi Janowca..., s. 51.

${ }^{15}$ W. Dworzaczek, Genealogia ..., s. 59. O takich praktykach wśród muzułmanów na przełomie XVIII i XIX w.: A. Kołodziejczyk, Przyczynek do historii Tatarów bialskich. Księga Matżeństw, Urodzin i Zgonów gminy mahometańskiej w Studziance ze zbiorów AP w Lublinie, „Archeion" 1986, t. LXXX, s. 229. 
łeczności polskich mahometan, którzy czasem korzystali z ksiąg rzymskokatolickich ${ }^{16}$.

Podkreślić jednak trzeba, że proboszczowie katoliccy często nie byli jedynymi urzędnikami stanu cywilnego w obrębie swoich parafii. Pogląd przeciwny pojawił się jeszcze w czasach Księstwa i wynikał z błędnej interpretacji art. 1 dekretu z 13 lutego 1809 r. ${ }^{17}$ Jak zauważył minister sprawiedliwości w marcu 1810 r.: „W egzekucji thumaczy się wyraz dekretu d.d. 23 lutego 1809 "duchowni obowiązki parafialne petniący« ściśle. Niektórzy katoliccy księża stosują go do obrębu geograficznego, zniewalając wyznawców innych religii w ich parafii mieszkających, ażeby przed nimi akta cywilne odbywali" ${ }^{\prime 18}$. Praktyki takie minister oceniał jednoznacznie negatywnie ${ }^{19}$. Problemu tego jednak nie rozwiązano poprzez zwiększenie liczby świeckich urzędników stanu cywilnego. Wręcz przeciwnie, z biegiem czasu w niektórych miejscowościach proboszczowie przejęli prowadzenie rejestrów od urzędników świeckich jeszcze przed reformą wprowadzoną Księgą Pierwszą Kodeksu Cywilnego Królestwa Polskiego ${ }^{20}$.

Z przeprowadzonej kwerendy wynika, że księża katoliccy zasadniczo przestrzegali form przewidzianych przez prawo państwowe, wymagające odnotowania nieco innych danych niż prawo kanoniczne. Czasem nawet spisywali akty rozwodów, od których sporządzania zwalniał duchownych art. 4 dekretu z 23 lutego 1809 r. $^{21}$

III. Podkreślenia wymaga, że nie tylko księża katoliccy, ale również duchowni innych wyznań pełnili obowiązki urzędników stanu cywilnego. $\mathrm{Na}$ przypomnienie zasługuje działalność w tym charakterze przełożonych parafii

${ }^{16}$ Np. Archiwum Państwowe w Lublinie, Akta stanu cywilnego Gminy Mahometańskiej w Studziance (35/1800), seria 1, t. 1, k. [22].

17 Dziennik Praw, t. I, s. 195.

18 AGAD, Rada Stanu i Rada Ministrów Księstwa Warszawskiego, seria 2, t. 76, s. 51.

19 Ibidem.

${ }^{20}$ Archiwum Państwowe w Płocku, Akta stanu cywilnego gminy Wyszogród, powiat płocki (50/370); Archiwum Państwowe w Łodzi, Akta stanu cywilnego Parafii Rzymskokatolickiej w Bąkowie (39/1394).

${ }^{21}$ Zgodnie z nim: „Końcem zaspokojenia troskliwości Religijnej Duchownych Katolickich, wyda Nasz Minister Sprawiedliwości do tychże Duchownych, Urzędnikami Stanu Cywilnego będących, Instrukcję, że nie są obowiązani ogłaszać Cywilnych rozwodów, ani zapowiadać rozwiedzionych jedynie cywilnie, ani też takim dawać Ślubów Cywilnych, lecz że do tego zostaną umocowanymi Prezydenci i Burmistrze, podług przepisów, które im przez Ministra Sprawiedliwości wydane zostaną, zastosowane do wszystkich pomienionych przypadków" (Dziennik Praw, t. I, s. 196); Archiwum Państwowe w Białymstoku, Oddział w Łomży, Akta stanu cywilnego Parafii Rzymskokatolickiej w Łomży, t. 58, akt nr 6; Archiwum parafialne parafii rzymskokatolickiej pw. Trójcy Przenajświętszej w Grajewie, Akta Zaślubienia Gminy Grajewskiej Powiatu Biebrzańskiego w Województwie Augustowskiem na rok 1821, akt nr 3. 
protestanckich $^{22}$, unickich ${ }^{23}$, prawosławnych ${ }^{24}$ i mahometańskich ${ }^{25}$. Spośród znaczniejszych grup religijnych jedynie Żydzi nie prowadzili własnych rejestrów, jako że zostali zawieszeni w prawach obywatelstwa ${ }^{26}$.

W miejscowościach wyznaniowo mieszanych działało więc nieraz równolegle dwóch (a czasem może i więcej) urzędników cywilnych, co powodowało niedogodności, na które zwracał uwagę minister sprawiedliwości w piśmie z 15 marca 1810 r.: „Każda parafia ma swój oddzielny obręb, który nie jest oraz [jednocześnie - P.Z.P.] obrębem politycznym. W jednym okręgu kraju mieszczą się parafie rozmaitych religii, z których każda znowu ma swoje oddzielne i niejednostajne granice i miejsca świątyń lub rezydencji kapłanów"27. $\mathrm{Z}$ tej różnorodności wynikały kłopoty, zarówno dla zwykłych obywateli, jak i dla sądów pokoju, które zgodnie z ustawą z 18 marca 1809 r. ${ }^{28}$ sprawowały pieczę nad urzędnikami stanu cywilnego, co w praktyce stwarzało problemy, gdyż podział na parafie miał się nijak do podziału na powiaty ${ }^{29}$.

Taka sytuacja miała miejsce, przykładowo, w Lesznie, gdzie powodowanemu przez nią zamieszaniu kres postanowił położyć monarcha, wydając 6 lutego 1813 r. na przełożenie ministra sprawiedliwości dekret, w którym zezwolił na powołanie w tym mieście jednego świeckiego urzędnika stanu cywilnego, który miał zastąpić występujących dotychczas w tej roli duchownych ${ }^{30}$.

${ }^{22}$ Na działalność pastorów w roli urzędników stanu cywilnego zwrócił uwagę Damazy Dzierożyński w: Instrukcja ..., s. 169; Archiwum Państwowe w Poznaniu, Akta stanu cywilnego Parafii Ewangelickiej Bnin (pow. śremski) (53/3767); Akta stanu cywilnego Parafii Ewangelickiej Margonin (pow. chodzieski) (53/3813), Akta stanu cywilnego Parafii Ewangelickiej Zaborowo (pow. leszczyński) (53/3875).

${ }^{23}$ Archiwum Państwowe w Lublinie, Akta stanu cywilnego Parafii Greckokatolickiej w Babicach (35/1617), Akta stanu cywilnego Parafii Greckokatolickiej w Berdyszczach (35/1618), Akta stanu cywilnego Parafii Greckokatolickiej w Bezwoli (35/1621), Akta stanu cywilnego Parafii Greckokatolickiej w Buśnie (35/1629), Akta stanu cywilnego Parafii Greckokatolickiej w Lubieniu (35/2051), Akta stanu cywilnego Parafii Greckokatolickiej w Laziskach (35/2054), Akta stanu cywilnego Parafii Greckokatolickiej w Losicach (35/2058), Akta stanu cywilnego Parafii Greckokatolickiej w Milejowie (35/2072), Akta stanu cywilnego Parafii Greckokatolickiej w Pawłowie (35/2092), Akta stanu cywilnego Parafii Greckokatolickiej w Świerżach (35/2148), Akta stanu cywilnego Parafii Greckokatolickiej w Tarnawie (35/2150), Akta stanu cywilnego Parafii Greckokatolickiej w Terebelli (35/2155).

${ }^{24}$ Archiwum Państwowe w Kielcach, Oddział w Sandomierzu, Akta stanu cywilnego grekoorientalnej cerkwi w Opatowie (24/658).

25 Archiwum Państwowe w Lublinie, Akta stanu cywilnego Gminy Mahometańskiej w Studziance (35/1800), seria 1, t. 1 i n.

${ }^{26}$ AGAD, Rada Stanu i Rada Ministrów Księstwa Warszawskiego, seria 2, t. 76, s. 51. Por. Dekret o zawieszeniu na okres lat dziesięciu wykonywania praw politycznych przez ludność żydowska zamieszkała w Księstwie Warszawskim, [w:] „Ustawodawstwo Księstwa Warszawskiego. Akty normatywne władzy najwyższej”, t. I: 1807-1808, oprac. W. Bartel, J. Kosim, W. Rostocki, Warszawa 1964, s. 148.

27 AGAD, Rada Stanu i Rada Ministrów Księstwa Warszawskiego, seria 2, t. 76, s. 49.

28 Dziennik Praw, t. I, s. 231 i n.

29 AGAD, Rada Stanu i Rada Ministrów Księstwa Warszawskiego, seria 2, t. 76, s. 49-51.

${ }^{30}$ Dziennik Praw, t. V, s. 1. 
IV. Trzecią kategorię stanowiły osoby świeckie, które kompleksowo prowadziły akta stanu cywilnego na danym terenie. Sytuacja, kiedy wykonywanie obowiązków z tym związanych była ich jedynym zajęciem, zachodziła raczej rzadko - w Warszawie i być może w Kaliszu ${ }^{31}$. Przeważnie świeccy - podobnie zresztą jak duchowni - prowadzili akta cywilne obok innych obowiązków zawodowych. Często byli to burmistrzowie miast ${ }^{32}$ lub kanceliści magistratu ${ }^{33}$. Znalazł się w tym gronie także przynajmniej jeden nauczyciel ${ }^{34}$.

V. Czwartą grupę urzędników stanu cywilnego stanowiły osoby świeckie działające na danym obszarze równolegle z proboszczami. Ogłaszały one tylko te akty, które pozostawały w sprzeczności z prawem kanonicznym (tj. rozwody, śluby wyłącznie cywilne i ich zapowiedzi). Taka sytuacja miała miejsce w Zamościu, gdzie w tej roli występował burmistrz ${ }^{35}$, w Kielcach, gdzie funkcję tę pełnił prezydent municypalności ${ }^{36}$, a także w Jastrzębiu w departamencie radomskim, gdzie $w$ roli tej wystąpiły dwie osoby jednocześnie burmistrz oraz - zapewne - jeden z kancelistów magistratu ${ }^{37}$. O ile w Zamościu i Kielcach zaprowadzono na potrzeby tych spraw osobne księgi, o tyle w Jastrzębiu w roku 1815 urzędnicy świeccy włączyli akt rozwodu do księgi prowadzonej w pozostałym zakresie przez miejscowego wikarego.

W podobnym kierunku podążyła - z czasem - praktyka w Łomży, gdzie w księgach prowadzonych przez miejscowego proboszcza trzy akty rozwodów sporządzono na trzy różne sposoby. W czerwcu 1814 r. rozwiązanie mał-

31 Tu urzędnicy stanu cywilnego tytułują się po prostu urzędnikami stanu cywilnego, a nie burmistrzami czy innymi urzędnikami sprawującymi funkcje urzędników stanu cywilnego (wyjątek stanowiła w pewnym okresie gmina ósma miasta stołecznego Warszawy). Poza rejestratorami z Warszawy w taki sposób określał się Feliks Walderowicz z Kalisza (przykładowo: w wyciągu z aktu urodzenia załączonym do akt sądowych - AGAD, Trybunał Cywilny Kaliski, t. 323, k. 431). Także urzędnikiem stanu cywilnego nazywa Walderowicza ks. Stanisław Załęski w: O masonii w Polsce od roku 1742 do 1822 na źródlach wytacznie masońskich, Kraków 1908, s. 147. Taka była również tytulatura Adama Heybowicza z Augustowa - Archiwum Diecezjalne w Łomży, sygn. 410, Akta rozwodowe Heybowiczów.

${ }^{32}$ Bąków [Archiwum Państwowe w Łodzi, Akta stanu cywilnego Parafii Rzymskokatolickiej w Bąkowie (39/1394)]; Bełchatów [Archiwum Państwowe w Łodzi, Akta stanu cywilnego gminy Bełchatów (39/1397)]; Pyzdry [AGAD, Trybunał Cywilny Kaliski, t. 313, k. 187-187v.], Błaszki [AGAD, Trybunał Cywilny Kaliski, t. 305, k. 223v.].

${ }^{33}$ W Płocku był to kasjer Szymon Dobrowolski, Archiwum Państwowe w Płocku, Akta stanu cywilnego gminy Płock 1808-1825 (50/357), przykładowo: t. 82.

34 Archiwum Państwowe w Płocku, Akta stanu cywilnego gminy Wyszogród, powiat płocki (50/370), t. 2 .

35 Archiwum Państwowe w Lublinie, Akta stanu cywilnego Parafii Rzymskokatolickiej w Zamościu (35/1954), t. 40: Księga ogłoszenia rozwodów i dawania ślubów cywilnych.

36 Archiwum Państwowe w Kielcach, Akta Urzędnika Stanu Cywilnego powiatu kieleckiego (21/1143), t. 1-6.

${ }^{37}$ Archiwum Państwowe w Radomiu, Urząd Stanu Cywilnego Parafii Rzymskokatolickiej Jastrząb (58/137), seria 1, t. 4: Akta cywilne parafi jastrzębiej z roku 1815, nienumerowana karta pomiędzy kartą 68 a 69 . 
żeństwa ogłosił tam miejscowy proboszcz ${ }^{38}$. W grudniu tego samego roku rozwód ogłosił już zastępca burmistrza, a następnie proboszcz wpisał go do ksiąg parafialnych ${ }^{39}$. Z kolei w roku $1816 \mathrm{w}$ tych samych księgach parafialnych spotykamy się z inną próbą rozwiązania konfliktu między prawem kanonicznym a państwowym. Proboszcz niejako użyczył prowadzonej przez siebie księgi stanu cywilnego burmistrzowi, który dokonał tam najpierw wpisu zapowiedzi ${ }^{40}$, a następnie wpisu małżeństwa wyłącznie cywilnego (kawalera $\mathrm{z}$ rozwódką) ${ }^{41}$. Ten ostatni przypadek przypomina zatem model zastosowany w Jastrzębiu.

VI. W zasadach konstytucji Królestwa Polskiego z 13/25 maja 1815 r. zapowiedziano zniesienie urzędników stanu cywilnego $\mathrm{w}$ dotychczasowym kształcie (art. 26). Stąd jeszcze w 1815 r. Rząd Tymczasowy Królestwa Polskiego przygotował stosowny projekt ${ }^{42}$. W samej konstytucji kwestię tę jednak przemilczano. Dotychczasowy model organizacji urzędów stanu cywilnego funkcjonował nadal ku niezadowoleniu kleru katolickiego i środowisk konserwatywnych, które donosiły władzom o przypadkach niechrzczenia dzieci i zawierania małżeństw wyłącznie cywilnych w Warszawie, gdzie pracowali świeccy urzędnicy ${ }^{43}$. Stąd też opracowywane w tym czasie projekty dotyczące funkcjonowania rejestrów stanu cywilnego pomijały osoby świeckie, które mogłyby dokonywać czynności sprzeczne z prawem kanonicznym. Jak zauważono w raporcie przygotowanym w związku z projektem rozpatrywanym na początku roku 1818 przez Zgromadzenie Ogólne Rady Stanu: „Zagęszczone u nas rozwody, osłabiając związki familijne, wpływ mają na wychowanie dzieci i los pokolenia przyszłego. Założy się temu tama, póki inne nie nastąpią prawa, usuwając urzędników, bez których wyroki rozwodowe żadnej ważności nie mają"44.

Dopiero jednak wejście w życie Księgi Pierwszej Kodeksu Cywilnego Królestwa Polskiego wyłączyło możliwość działania świeckich urzędników stanu cywilnego w stosunku do chrześcijan. Połączono wówczas akta stanu cywilnego z metrykami kościelnymi (art. 71). Z kolei dla wyznawców religii niechrześcijańskich oraz chrześcijan, „dla których w miejscu zamieszkania [...] nie są urządzone parafie, wyznaczy Komisja Rządowa Wyznań Religij-

38 Archiwum Państwowe w Białymstoku, Oddział w Łomży, Akta stanu cywilnego Parafii Rzymskokatolickiej w Łomży, t. 58, akt nr 6.

39 Ibidem, t. 58, akt nr 53.

${ }^{40}$ Ibidem, t. 60, akt nr 11 na kartach 29-29v.

${ }^{41}$ Ibidem, t. 60, akt nr 11 na kartach 6-7.

42 AGAD, Rada Stanu Królestwa Polskiego, seria 2, t. 221, s. 1 i n.

43 AGAD, Rada Stanu i Rada Ministrów Księstwa Warszawskiego, seria 2, t. 76, s. 43. We Francji miały się zdarzać przypadki odwrotne, tj. chrzczenie dziecka bez informowania urzędnika stanu cywilnego o narodzinach. G. Noiriel, L'identification des citoyens..., s. 9 i 13.

44 AGAD, Rada Stanu i Rada Ministrów Księstwa Warszawskiego, seria 2, t. 76, s. 45. 
nych osoby do spisywania aktów stanu cywilnego" (art. 92). Zatem w nowym stanie prawnym działalność świeckich urzędników stanu cywilnego została poważnie ograniczona. Odtąd mieli się oni zajmować głównie rejestracją narodzin, małżeństw i zgonów Żydów zamieszkałych w poszczególnych okręgach bożniczych (acz wypada zauważyć, że częstokroć przejęli te obowiązki od przełożonych parafii rzymskokatolickich ${ }^{45}$ ).

Jednocześnie po osiemnastu latach obowiązywania prawa świeckiego, miejscami niezgodnego z zasadami poszczególnych wyznań, dostosowano prawo państwowe do reguł wszystkich obrządków praktykowanych przez większe grupy mieszkańców Królestwa. Pamiętać trzeba, że krytykowana przez Kościół katolicki instytucja rozwodu nie była jedynym problemem. Żydom kłopot sprawiało przestrzeganie uregulowań dotyczących aktów narodzin, ponieważ zgodnie z prawem mojżeszowym imię dziecku można nadać dopiero po ośmiu dniach ${ }^{46}$, podczas gdy Kodeks Napoleona wymagał spisania aktu urodzenia w ciągu trzech dni od porodu (art. 55). W akcie rzecz jasna należało podać imię dziecka (art. 57). Kodeks Cywilny Królestwa Polskiego wyłączał możliwość uzyskania rozwodu przez katolików, a termin na sporządzenie aktu urodzenia wydłużył do ośmiu dni (art. 96).

Z przeprowadzonej kwerendy wynika, że zasady sporządzania aktów stanu cywilnego były zasadniczo przestrzegane zarówno przez duchownych, jak i świeckich rejestratorów. Wśród istotniejszych naruszeń obowiązującego prawa można wymienić spisywanie przez niektórych pastorów akt stanu cywilnego w języku niemieckim, co pozostawało w sprzeczności z art. 84 konstytucji Księstwa Warszawskiego ${ }^{47}$.

Szkic ten bynajmniej nie omawia kompleksowo wszelkich problemów badawczych związanych z funkcjonowaniem francuskiego modelu rejestracji stanu cywilnego na centralnych ziemiach polskich. Wręcz przeciwnie - pokazuje, że kwestie te znamy ciągle bardzo słabo. Zwłaszcza zaś zagadnienie działalności świeckich urzędników stanu cywilnego, która - jak pokazano była wcale szeroka, choć - na obecnym etapie badań - nie można określić jej skali. Nie wiemy, jaki odsetek aktów sporządzali w badanym okresie świeccy rejestratorzy. Skromne są też informacje na temat samej zbiorowości świeckich urzędników stanu cywilnego. Opisu nie ułatwia okoliczność, że prowadzeniem rejestrów zajmowali się oni przeważnie niejako przy okazji sprawowania innych funkcji publicznych. Badania aktów stanu cywilnego, które

${ }^{45}$ Np. P. Sygowski, Żydzi Janowca..., s. 53.

46 AGAD, Rada Stanu i Rada Ministrów Księstwa Warszawskiego, seria 2, t. 76, s. 52.

47 Np: Archiwum Państwowe w Poznaniu, Akta stanu cywilnego Parafii Ewangelickiej Bnin (pow. śremski) (53/3767), t. 5. Z kolei w miasteczku Śmigiel część aktów spisywano zarówno po polsku, jak i po niemiecku: Archiwum Państwowe w Poznaniu, Akta stanu cywilnego Parafii Rzymskokatolickiej Śmigiel (pow. kościański) (53/3524), seria I, t. 1. 
zachowały się do naszych czasów w nieporównanie większym procencie niż spuścizny sądów i administracji z pierwszej ćwierci XIX wieku, dają ponadto nadzieję na znaczące poszerzenie naszej wiedzy o stosowaniu francuskiego prawa w praktyce. Źródła te - jak dotąd - w bardzo niewielkim stopniu wykorzystano też na potrzeby demografii historycznej, do której rozwoju mogą się walnie przyczynić.

\section{Aneks}

AGAD, Rada Stanu i Rada Ministrów Księstwa Warszawskiego, s. II, t. 76, s. 1-2; [rkps A]

Archiwum Diecezjalne w Łomży, Akta Urzędników Stanu Cywilnego, sygn. 448, k. $11 \mathrm{v}-12$ [rkps B]

Urządzenie urzędników [aktów] ${ }^{48}$ cywilnych w Księstwie Warszawskim

1 Wszyscy burmistrze, prezydenci lub pod jakimkolwiek nazwiskiem przełożeni w mieście zastąpią urzędników aktów cywilnych do dalszych rozkazów Najjaśniejszego Pana.

2 We wsiach, w których są parafie, a nie masz znacznej ilości Żydów, księża proboszcze zastąpią urzędników aktów cywilnych do dalszego rozkazu Jego Królewskiej Mości.

3 Gdzie wiele jest różnowierców i gdzie można znaleźć zdatnego organistę, ten może zastępować urzędnika aktów cywilnych.

4 Podprefekci imię zapiszą, wieś, parafię i uwiadomią prefekta o każdym ustanowionym Urzędniku Aktów Cywilnych.

5 Prefekt raporta od podprefektów komunikować ma sądom departamentowym. Odda wraz zbytnie podpisy ministra sprawiedliwości jako i instrukcje.

6 W Warszawie dobierać się będzie z obywatelów na Urzędników Aktów Cywilnych ośmiu, których magistrat przedstawi prefektowi, a ten doniesie [JW. ${ }^{49}$ Ministrowi Spraw Wewnętrznych, który o nich uwiadomi JW Ministra Sprawiedliwości.

$7 \quad$ Z departamentowych miast prefekci doniosą, gdzie usądzą potrzebę pomnożenia liczby urzędników aktów cywilnych.

8 Opłaty od tych czynów za nadesłanymi rozkazami Najjaśniejszego Pana ogłoszone zostaną.

$9^{50}$ Urządzenie to tymczasowe ma tylko do dalszych rozkazów Najjaśniejszego Pana mieć swoje trwanie ${ }^{51}$.

48 Słowo pominięte w rkps B.

49 Skrót pominięty w rkps B.

${ }^{50} \mathrm{~W}$ rkps A numer ten pominięto.

${ }^{51} \mathrm{Na}$ końcu obu rękopisów znajduje się informacja, że oryginalny dokument podpisali ministrowie Łubieński i Łuszczewski. 


\title{
THE FRENCH MODEL OF CIVIL REGISTRY IN POLAND
}

\author{
Summary
}

The functioning of the French model of Civil Registry in the Duchy of Warsaw governed by the Napoleonic Code is analysed. Under the provisions of the Code, it was the Catholic parish priests who were responsible for keeping civil records. Civil registrars were appointed occasionally, and in towns with Protestant predominance, civil records were kept simultaneously by the Catholic parish priests (for the Catholics) and the Protestant clergymen (for the Protestants). The same pattern was followed in parishes populated by Orthodox Christians or the followers of the Ukrainian Greek Catholic Church.

Civil registrars would usually keep all civil registers but from time to time they worked alongside local parish priests. Their activity was then reduced to noting down the events not covered by the cannon law (such as e.g. civil divorce or entering into marriage by divorcees). What is more, the jurisdictions of registrars did not always reflect the administrative division of the country (the Duchy of Warsaw and later transformed into the Congress Kingdom of Poland) which had in consequence led to situations where more than one civil registrar were responsible for a given territory. All this taken into account, the reception of the French model of civil registry in Poland was not very successful.

\section{LE FONCTIONNEMENT DU MODĖLE FRANÇAIS DES REGISTRES D’ÉTAT CIVIL EN POLOGNE}

\author{
Résumé
}

L'article est une esquisse de la problématique relative au fonctionnement pratique du modèle français permettant l'enregistrement des actes d'état civil sur le territoire de la Pologne centrale. On connaît relativement bien les questions liées aux obligations à observer en la matière par les curés de l'Église catholique, l'auteur de l'article se concentre donc dans son travail sur la description des aspects en rapport avec le rôle des hommes d'autres églises et confessions et les soucis résultant de la non conformité entre le droit public et le droit canonique. Les officiers tiennent parfois les actes d'état civil dans leur ensemble, mais des fois, ils les tiennent en parallèle avec le curé de leur localité, se limitant, en l'occurrence, à noter juste tout évènement non conforme au droit canonique. Le domaine d'activité de chacun des officiers de l'état civil est souvent complètement indépendant du partage administratif du Duché de Varsovie et plus tard, de celui du Royaume de Pologne, car il dépend de la division en paroisses de l'Église catholique romaine et d'autres organisations confessionnel- 
les. Dans la même localité, on trouve donc parfois plusieurs officiers de l'état civil. L'adoption du modèle organisationnel français a donc réussi partiellement, mais finalement plus que l'on n'a pensé. 